\title{
Relationship between faculty staff professionalism and nursing students' values
}

\author{
Sanaa Abd ElAzim Ibrahim *1, Shereen Ahmed Qalawa ${ }^{2}$ \\ ${ }^{1}$ Nursing Administration Department, Faculty of Nursing, Port Said University, Egypt \\ ${ }^{2}$ Medical Surgical Nursing Deparment, Faculty of Nursing, Port Said University, Egypt
}

Received: February 5, 2016

DOI: $10.5430 /$ jnep.v6n9p38
Accepted: April 5, 2016

URL: http://dx.doi.org/10.5430/jnep.v6n9p38

\begin{abstract}
Background: The professional competencies of faculty staff are of great importance in shaping students' values, skills and attitudes that directly affect subsequent patient care. Objectives: to assay the level of faculty staff professionalism through investigating the level of professional competencies of faculty staff and behavior via students' perceptions, assessing nursing students' values, and finding the relationship between faculty staff professionalism and nursing students' values.

Methods: A descriptive correlational study design was carried out with 186 nursing students from four levels in the Faculty of Nursing, Port Said University, Egypt. A structured questionnaire was used to collect the data.

Results: Faculty staff had a high level of competencies, including: personality and respectful professional relationships and communication (75.3\%); planning and preparation, well-organized teaching methods (72.0\%); Activities of monitoring and giving feedback (72.6\%), Scientific and professional competence (68.3\%); and Methods of motivation and enhancement (67.7\%). About half of students (51.6\%) perceived that their faculty staff behave positively to a high level. Prominent values among nursing students are mercy, honesty and patience. Statistically significant relations were found between total faculty staff behavior scores, total faculty staff competencies scores, and total students' values scores, with statistically significant relations found for most items between faculty staff behaviors and competencies and students' values.

Conclusions and recommendations: The present study found that values as mercy, honest and patience had a great influence by the faculty staff professional competencies and positive behavior. It is recommended to enhance the scientific and professional level of faculty staff by continuous training and scholarships. Faculty staff must pay attention to guide students toward positive behavior and stress the importance of personal and professional students' values, reflected in their clinical nursing practice.
\end{abstract}

Key Words: Faculty staff, Professionalism, Competencies, Nursing students, Values

\section{INTRODUCTION}

\subsection{Background}

Faculty staff members are professionals engaged in interactive behavior with one or more students for the purpose of affecting knowledge (cognitive), skill (psychomotor) or feeling states (affective) change. This designation distinguishes the teacher from instructional materials and other school personnel. ${ }^{[1]}$ Faculty staff members comprise an im- portant factor in determining the quality of education, and their professionalization has been at the center of much concern among educators and researchers. Its importance is not only for professionalism and differentiation from members of other professions, but in a sociological sense, as a form of social development. ${ }^{[2]}$ Professionalism is an elusive concept, defined by sets of attitudes and behaviors attributed to specific professions. ${ }^{[3]}$ Professionalism consists of the attitudes

*Correspondence: Sanaa Abd ElAzim Ibrahim; Email: sanaaalaa355@gmail.com; Address: Faculty of Nursing, Port Said University, Egypt. 
and behavior one possesses toward one's profession. It is an attitudinal and behavioral orientation that individuals possess toward their career. ${ }^{[4]}$

However, teacher competences and professional standards are not the same thing. Professional standards concern what educators are expected to know and be able to do, associated with accountability and quality mechanisms, and closely linked with the actions of institutional and professional staff. ${ }^{[5]}$ Professional competencies as part of faculty staff professionalism are group of abilities and knowledge developed and acquired during their job orientation and running careers in addition to acquired experience and continuing education. ${ }^{[6]}$ Furthermore, professional attitudes and behaviors represent cornerstone of professionalism. ${ }^{[7,8]}$ Many factors influence faculty staff members' professionalism, such as the attitudes of different educational stakeholders towards them, gender, age and duration of service. These all have a bearing on their professionalism and implied performance in and outside class. ${ }^{[2]}$

Additionally, personality types lend a flavor to the leadership behavior of such faculty staff in effecting discipline in classroom situations. Learning environment discipline is associated with higher student motivation, good academic performance, and improved attitudes towards teaching staff. ${ }^{[1]}$ The classroom climate effectively controlled and influenced by staff members has a major impact on students' motivation and attitude towards learning; teaching staff equipped with professional characteristics influence students to establish a positive, learnable and teachable classroom climate. From the students' points of view, faculty staff expressive characteristics such as warmth, enthusiasm and extroversion apparently separate effective from ineffective teachers. ${ }^{[9]}$ The effective attitudes and actions employed by teachers ultimately can make a positive difference on the lives of their students, and their personal and professional beliefs. ${ }^{[10,11]}$ Although the strong effect of teachers would significantly influence students' academic achievement, other factors such as socio-economic background, family support, intellectual aptitude of student, personality of student, self-confidence, and previous instructional quality also have major impacts on academic outcomes. ${ }^{[2]}$

Moreover, everyone has a personal philosophy of life, which is unique from all others, and which people develop with age and experience. These philosophies serve as blueprints or guides and incorporate each individual's value and belief systems. ${ }^{[12]}$ From another perspective, physical appearance, attractiveness and professionalism have been identified as factors that have the potential to impact student perceptions of the faculty staff. These prior studies raise the specific ques-

Published by Sciedu Press tion of whether the attire worn by a faculty member in the classroom can impact student perceptions of the instructor's credibility, and thus their actual teaching effectiveness. ${ }^{[13]}$

Values are known internationally by a number of names, including moral education and character education. ${ }^{[14]}$ Each variant has a slightly different meaning, pointing to one or other distinctive emphasis. This is not an attempt to supplant the influences of the home but rather to supplement them and, where necessary, to compensate for them. International research into teaching and schooling effects is overturning earlier beliefs that values were exclusively the preserve of families and/or religious bodies and that, as a result, the learning environment functions best in a value-neutral mode; rather, values and effective teaching are inextricably interwoven, and values education goes to the heart of the role of the teacher and effective learning for the student, especially in nursing careers that yield a product (qualified nurses) who must exhibit highly developed ethical values. ${ }^{[15,16]}$

The professional attitudes of educators in the learning environment can positively attract and affect students' attitudes and foster required professional values. Moreover, increased student-staff interaction makes students feel valued and results in greater engagement with the learning process, and allowing students the opportunity to constructively challenge their educators' ideas will enhance their achievement and enthusiasm. ${ }^{[17]}$

Finally, it is very important to find the characteristics of faculty staff members' behavior, attitudes, knowledge, skills and their impacts on the academic achievement of university students. Therefore, at the university level, faculty staff positive behavior, interaction with students, professional competencies, teaching skills, parental involvement, students' own capabilities and university environment all play critical roles to strengthen the potential required for better academic achievement of nursing students and to cultivate ethical values in the hearts and minds of students to equip them for a fruitful and effective nursing career advocating and supporting patients' rights. ${ }^{[18]}$

\subsection{Objectives}

(1) Determine level of faculty member's professionalism in terms of:

- Level of professional competencies among faculty staff as perceived by nursing students

- Level of faculty staff behaviour as perceived by nursing students

(2) Determine degree of nursing students' values.

(3) Find out the relationship between faculty staff professionalism and nursing students' values. 


\subsection{Research questions}

(1) What is the level of professionalism among faculty members?

(2) What are the degrees of nursing students' values?

(3) Is there a relationship between faculty staff professionalism and nursing students' values?

\subsection{Operational definitions}

Professionalism as a personal characteristic is revealed in an attitude and approach to an occupation that is commonly characterized by intelligence, integrity, maturity, and thoughtfulness. Professionalism means behaving in an ethical manner and fulfilling one's responsibilities in all situations with appropriate behavior, attitudes and communication, while competencies define the applied skills and knowledge that enable people to successfully execute their roles.

Values measure of the worth or importance a person attaches to something; values are often reflected and shaped by the ways in which people live and operate within the private and public sphere.

\section{MeTHODS}

\subsection{Research design}

A descriptive correlational design was utilized to conduct this study.

\subsection{Ethical considerations}

Ethical approval was obtained from the administrative authorities of the College of Nursing, Port Said University, Egypt, from which participants were voluntarily recruited. The aim of the study was explained to nursing students, and participation was entirely voluntary. All participants had an opportunity to determine their willingness or refusal to participate in the study without being affected in any way.

\subsection{Participants and setting}

The study questionnaire was distributed to 291 students, of whom 186 subsequently completed and returned them (response rate 64\%). They were given the option to keep their identities anonymous by not writing their names from four levels at the Faculty of Nursing, Port Said University, Egypt, during the academic year 2013-2014 at the end of second semester.

\subsection{Instruments}

Data collected using questionnaire sheet were divided into four parts; the first part is the demographic characteristics of the study sample; the second part is students' perception of faculty professionalism questionnaire adopted from Eisa and
Elnaqa (2008), ${ }^{[19]}$ consisting of 61 sub-items of five basic dimensions of the professional competencies:

(1) Personality (17 items) includes questions on appearance, respectful professional relationships and communication.

(2) Planning (18 items) includes questions on preparation, well-organized teaching methods.

(3) Activating, monitoring and giving feedback to students (11 items) includes questions on encouraging creativity and giving positive critique.

(4) Scientific and professional faculty staff competence (9 items) includes questions on broad advanced knowledge and mastery of scientific content.

(5) Abilities of enhancement and motivation (6 items) includes questions concerning the appreciation of students' achievement.

The 61 items are answerably by yes, no and sometimes answers which are scored 2,1 and 0, respectively. The third part is concerned with students' perception of faculty staff behavior. It includes 20 items derived from Hoffman (2012), ${ }^{[20]}$ after some modifications and translation to Arabic language, to explore the students' perception regarding faculty staff behavior and occurrences rate of these attitudes. It includes 20 items, such as Arriving late, Cancelling without notice, Being unprepared, Punishing entire class for one student's behavior, Threatening to fail a student, Not allowing open discussion. It is answerable with five-point Likert-type scales (1='strongly disagree' to $5=$ 'strongly agree'). The occurrence of negative attitudes is indicated by $<60 \%$ while positive attitudes are represented by $\geq 60 \%$. Finally, the fourth part was regarding students' values questionnaire. It was contains 13 items to assess students' perception and presence degree of student values as honesty, patience, secretariat, tolerance, justice, mercy, sincerity, dream humility, love of science and importance of students' civility, based on AlOsaimi (2006). ${ }^{[21]}$ It was answered by scores of 1 to 3 , for which $1=$ 'no presence', $2=$ 'simple presence' and 3='great present', whereby scores $<60 \%$ indicate low quality of students' values and $\geq 60 \%$ reflect high student values.

\subsection{Procedure}

After searching related literature and choosing the appropriate tool to address the study objectives, the English parts of questionnaire (i.e. the third and fourth parts) were translated into Arabic and back-translated so English experts could check the fidelity of the translated instrument. Validity was checked using the application of Delphi technique by five nursing educators from the Faculty of Nursing, and necessary modifications were undertaken according to technique. The tool's reliability tested by Cronbach's alpha coefficient 
scored as follows: faculty staff professional competencies, 0.98 ; faculty staff behavior 0.97 ; and student values (0.93). These scores indicate the high reliability of the questionnaire. The applicability of the questionnaire was tested and then necessary modifications were undertaken according to the finding results of the pilot study, which was carried out with $10 \%$ of students. Students who participated in the pilot were then excluded from the sample of research work to assure the stability of answers.

Data were collected through distributing the questionnaire to students, who individually filled the questionnaire collected from April to June 2014, according to the availability of students' attendance. The purpose of the study was explained prior to administering the questionnaire sheet, and the time needed to answer it ranged from 25 to 35 minutes. Data were revised, coded, entered, analyzed and tabulated using SPSS version 19. Both descriptive statistics (frequency, percentage) and inferential statistics (Pearson correlation: Spearman coefficient tests) were used, according to the type of variables.

\section{RESUlts}

More than one quadrant of the 186 sampled nursing students were expatriates, and most students were aged over twenty. More than half of them were females. With regard to to the level of faculty professionalism, there was found to be underexpression of professional competencies, as shown portrayed in Table 1. Nursing students expressed that their faculty staff had high level of competencies regarding the five main faculty competencies of: personality - faculty staff abilities to communicate, and deal with respectful professional relationships (75.3\%); planning and preparation - well-organized teaching methods (72.0); activities of monitoring and giving feedback (72.6); scientific and professional competence (68.3); and methods of motivation and enhancement (67.7).

Table 1. Level of faculty staff professional competencies as perceived by students

\begin{tabular}{|c|c|c|c|c|}
\hline \multirow{2}{*}{$\begin{array}{l}\text { Faculty staff professional } \\
\text { competencies }\end{array}$} & \multicolumn{2}{|c|}{ Low $<60 \%$} & \multicolumn{2}{|c|}{ High $\geq 60 \%$} \\
\hline & No. & $\%$ & No. & $\%$ \\
\hline $\begin{array}{l}\text { Personality and respectful professional } \\
\text { relationships and communication }\end{array}$ & 46 & 24.7 & 140 & 75.3 \\
\hline $\begin{array}{l}\text { Planning and preparation, } \\
\text { well-organized teaching methods }\end{array}$ & 52 & 28.0 & 134 & 72.0 \\
\hline $\begin{array}{l}\text { Activities of monitoring and giving } \\
\text { feedback }\end{array}$ & 51 & 27.4 & 135 & 72.6 \\
\hline Scientific and professional competence & 59 & 31.7 & 127 & 68.3 \\
\hline $\begin{array}{l}\text { Methods of motivation and } \\
\text { enhancement }\end{array}$ & 60 & 32.3 & 126 & 67.7 \\
\hline
\end{tabular}

Table 2 reveals that $51.6 \%$ of nursing students perceived that the faculty behave positively, with high performance in $49.5 \%$ of cases, while the occurrence of negative faculty staff behavior was reported as $32.8 \%$. Table 3 shows that the most important values among nursing students are mercy, honesty, and patience (39\%, 38.2\% and 36\%, respectively). Table 4 indicates a statistically significant relationship between total faculty staff behaviors scores and total faculty staff professional competencies scores and total students' values scores. Table 5 shows that the most statistically significant relations were between faculty staff behavior scores and faculty staff professional competencies scores and students' values scores.

Table 2. Level of faculty staff behaviors as perceived by nursing students $(n=186)$

\begin{tabular}{|c|c|c|c|c|}
\hline \multirow{2}{*}{ Faculty staff behavior } & \multicolumn{2}{|c|}{ Low $<60 \%$} & \multicolumn{2}{|c|}{ High $\geq 60 \%$} \\
\hline & No. & $\%$ & No. & $\%$ \\
\hline Positive behavior rate & 90 & 48.4 & 96 & 51.6 \\
\hline Occurrence & 94 & 50.5 & 92 & 49.5 \\
\hline Negative behavior rate & 95 & 51.1 & 91 & 48.9 \\
\hline Occurrence & 125 & 67.2 & 51 & 32.8 \\
\hline
\end{tabular}

Table 3. Existence of values among nursing students $(n=$ 186)

\begin{tabular}{|c|c|c|c|c|c|c|}
\hline \multirow{2}{*}{$\begin{array}{l}\text { Student } \\
\text { values }\end{array}$} & \multicolumn{2}{|c|}{ Not found } & \multicolumn{2}{|c|}{ Simple } & \multicolumn{2}{|c|}{ Great } \\
\hline & No & $\%$ & No. & $\%$ & No. & $\%$ \\
\hline Truth & 53 & 28.5 & 79 & 42.5 & 54 & 29.0 \\
\hline Patience & 52 & 28.0 & 67 & 36.0 & 67 & 36.0 \\
\hline Honest & 50 & 26.9 & 65 & 34.9 & 71 & 38.2 \\
\hline Tolerance & 61 & 32.8 & 62 & 33.3 & 63 & 33.9 \\
\hline Justice & 59 & 31.7 & 73 & 39.2 & 54 & 29.0 \\
\hline Mercy & 47 & 25.3 & 66 & 35.5 & 73 & 39.2 \\
\hline Faith & 43 & 23.1 & 79 & 42.5 & 64 & 34.4 \\
\hline Dream & 57 & 30.6 & 63 & 33.9 & 66 & 35.5 \\
\hline Humility & 54 & 29.0 & 71 & 38.2 & 61 & 32.8 \\
\hline $\begin{array}{l}\text { Love of } \\
\text { learning }\end{array}$ & 53 & 28.5 & 72 & 38.7 & 61 & 32.8 \\
\hline
\end{tabular}

Table 4. Correlation between total student values with staff behavior and efficiency of staff members subscales

\begin{tabular}{lll}
\hline \multirow{2}{*}{ Professionalism } & \multicolumn{2}{l}{ Student values } \\
\cline { 2 - 3 } & $\boldsymbol{r}$ & $\boldsymbol{p}$ \\
\hline Faculty staff behavior & $-0.207^{*}$ & $.005^{*}$ \\
Faculty staff professional competencies & $0.158^{*}$ & $.032^{*}$ \\
\hline
\end{tabular}

Note. $r$ : Pearson coefficient; *: Statistically significant at $p \leq .05$ 
Table 5. Correlation between professional competencies of staff subscales with student values

\begin{tabular}{|c|c|c|c|c|c|c|c|c|c|c|c|c|}
\hline & & Truth & Patience & Honesty & Tolerance & Justice & Mercy & Faith & Dream & Humility & $\begin{array}{l}\text { Love } \\
\text { science }\end{array}$ & $\begin{array}{l}\text { Total } \\
\text { value }\end{array}$ \\
\hline $\begin{array}{l}\text { Personality } \\
\text { competence }\end{array}$ & $r_{s}$ & 0.139 & 0.084 & $0.243^{*}$ & $0.160^{*}$ & $0.184^{*}$ & $0.188^{*}$ & $0.174^{*}$ & $0.277^{*}$ & $0.159^{*}$ & $0.159^{*}$ & $0.223^{*}$ \\
\hline $\begin{array}{l}\text { Planning } \\
\text { competence }\end{array}$ & $r_{s}$ & 0.114 & 0.067 & $0.219^{*}$ & 0.119 & 0.120 & $0.161^{*}$ & 0.098 & $0.147^{*}$ & 0.066 & 0.103 & $0.145^{*}$ \\
\hline $\begin{array}{l}\text { Activities of } \\
\text { monitoring } \\
\text { and giving } \\
\text { feedback }\end{array}$ & $r_{s}$ & 0.021 & 0.007 & $0.146^{*}$ & 0.076 & 0.068 & 0.062 & 0.023 & 0.111 & 0.004 & 0.033 & 0.078 \\
\hline $\begin{array}{l}\text { Scientific and } \\
\text { professional } \\
\text { competence }\end{array}$ & $r_{s}$ & 0.035 & 0.013 & $0.152^{*}$ & 0.047 & 0.053 & 0.046 & 0.045 & 0.124 & 0.050 & 0.081 & 0.079 \\
\hline $\begin{array}{l}\text { Methods of } \\
\text { motivation }\end{array}$ & $r_{s}$ & 0.036 & 0.019 & 0.131 & 0.035 & 0.024 & 0.075 & 0.009 & 0.108 & 0.038 & 0.082 & 0.071 \\
\hline $\begin{array}{l}\text { Positive } \\
\text { behavior }\end{array}$ & $r_{s}$ & -0.096 & -0.136 & -0.114 & -0.091 & -0.064 & -0.119 & -0.115 & -0.089 & -0.111 & -0.093 & -0.114 \\
\hline $\begin{array}{l}\text { Negative } \\
\text { behavior }\end{array}$ & $r_{s}$ & $-0.200^{*}$ & $-0.213^{*}$ & -0.125 & -0.070 & -0.137 & $-0.190^{*}$ & $-0.192^{*}$ & -0.122 & -0.137 & $-0.156^{*}$ & $-0.170^{*}$ \\
\hline $\begin{array}{l}\text { Positive } \\
\text { occurrence }\end{array}$ & $r_{s}$ & $-0.160^{*}$ & -0.143 & -0.093 & -0.074 & -0.127 & $-0.185^{*}$ & $-0.260^{*}$ & $-0.192^{*}$ & $-0.177^{*}$ & $-0.155^{*}$ & $-0.190^{*}$ \\
\hline $\begin{array}{l}\text { Negative } \\
\text { occurrence }\end{array}$ & $r_{s}$ & $-0.213^{*}$ & -0.141 & $-0.184^{*}$ & -0.096 & $-0.166^{*}$ & $-0.211^{*}$ & $-0.197^{*}$ & $-0.219^{*}$ & -0.139 & $-0.215^{*}$ & $-0.213^{*}$ \\
\hline
\end{tabular}

Note. $r_{s}$ : Spearman coefficient; *: Statistically significant at $p \leq .05$

\section{Discussion}

Nurses at the present time are facing various personal and interpersonal, professional and institutional, and socio-cultural challenges in their professional performance, and it is not always easy to navigate the general development of the profession that is underway. The lack of one correct approach in addressing different contextual issues may lead to ethical dilemmas. Responding to these complex issues demands that nurses acquire comprehensive ethical knowledge and skills in various decision-making processes. Teaching materials have a pivotal role to play in helping nurses in this endeavor. ${ }^{[12]}$ The questions asked by this study are discussed below in relation to the findings.

\section{Part I: What is the level of professionalism among fac- ulty members?}

The study illuminated the level of faculty professionalism as expressed by students under five main competencies. For personality and communication, the results reflected that more than three-quarters of students recorded a high level of faculty abilities to communicate and deal with students professionally and respectfully. These findings corroborate those of Parandeh et al. ${ }^{[22]}$ who considered the effect of educational, cultural and individual factors in developing nurses' professional values. Moreover, students' perceptions of professionalism that may reflect whether the current education process promotes professional values and behaviors for healthcare. This study focused on Ankara University Faculty of Medicine students' perceptions of 'a good doctor', providing insights into what are considered desirable traits and how these can be acquired. Structured educational activities concerning professionalism are considerably limited in which may highlight shortcomings in relying largely on informal, 'hidden' curricula. ${ }^{[23]}$

Regarding to second and third faculty staff competencies of planning and preparation, well-organized teaching methods and activities of monitoring and giving feedback, the results reflected that slightly less than three-quarters of students recorded a high level of well-planned, structured and prepared course content with an organized method of teaching. This is in-line with Wesson, ${ }^{[24]}$ who found that educators have much in common with actors, especially when they view the lecture experience as a type of performance assisting student engagement. Performance skills such as vocalization, eye contact, being spatially aware and a teacher's obvious display of passion were cited as examples of this. Copriady ${ }^{[25]}$ pointed out that abilities and competencies in more traditional pedagogical tasks such as developing instructions, lesson planning, preparing, implementing and translating the 
process in the form of continuous assessment and feedback throughout the teaching process in the theory and laboratory is more important.

\section{Part II: What are the degrees of nursing students' val- ues?}

More than two-thirds of students expressed that their faculty staff have high-level competencies regarding methods of students' motivation and enhancement and scientific and professional competence. Regarding scientific and professional competence, this is supported by the ethos and policies of life-long learning promoted by global universities to match rapid progress in the scientific field. Port Said School of Nursing adopted self-learning approach and problem-based learning to equip students for independent, life-long learning, and to enhance their abilities to search and collect updated content related to subject matter. This also supports students to judge instructors' level of scientific and professional competence.

As found by Wilfongetal, ${ }^{[26]}$ this study appreciates that nursing is a demanding professional career requiring commitment to lifelong learning, and continual effort to gain new knowledge, skills and abilities. Motivation and enhancement were thus identified as key in pushing and encouraging nursing students to achieve success, confirming Copriady, ${ }^{[25]}$ who concluded that instructors' competency is related to how teachers influenced students through motivating and influencing them by fostering positive attitudes to learning and providing appropriate feedback on their learning activities. Moreover, Shah ${ }^{[18]}$ illustrated that the competences of faculty staff to motivate students to learn and develop supportive relationships positively affected students' values and shaped their attitudes.

Regarding staff members' behaviors as perceived by students, the present study revealed that more than half of nursing students perceived that the behaviors of faculty staff were positive. This corroborates the findings of $\mathrm{Shah}^{[18]}$ and Camp, ${ }^{[27]}$ who also reported that teachers' expectations of students' academic performance has a powerful effect on how students feel about themselves and how they actually perform academically. Students who receive positive expectation messages tend to live up to these expectations and perform well.

Concerning students' values, the present study revealed that about two-fifths of students ranked the values of mercy, honesty and patience as highly important, in-line with Reimers, ${ }^{[28]}$ Alt and Reingold ${ }^{[29]}$ and Lovat and Hawkes, ${ }^{[16]}$ who expressed that when the learning environment has a medium for developing values through emphasizing 'common decency' orientation in the field of 'moral' commitment and the existence of role models, and without any other explicit contaminating factor being present, it is possible to educate students to understand and appreciate values that include compassion and caring, concern for others, respect and reciprocity and prepare and encourage students for global citizenship.

Professionalism is defined as the specialty, knowledge, skill and behavior pattern being displayed in their profession. Also, its values and beliefs guide the nurse, who is in an interaction with the patient. ${ }^{[30]}$

\section{Part III: Is there a relationship between faculty staff pro- fessionalism and nursing students' values?}

Regarding the relationship between faculty staff professionalism (competencies and behaviors) and students' values, the current study revealed that statistically significant differences were found between faculty staff behaviors and competencies with students' values. This finding supports Tope ${ }^{[1]}$ who identified that staff who handle most student behavioral problems and only refer those with very severe problems to a counselor are able to maintain very close working relationships that help students to cultivate positive values, and to be adjusted to school and subsequently professional life.

Additionally, Mercader ${ }^{[31]}$ drew on Morrill (1980) to observe that a college's impact on undergraduates was significantly different from what the alumni reported a number of years after graduation. The alumni ranked the college's effects after attending as stability of self-concept, stability of values, integration of self-concept, integration of values, development of all centric values, and development of all centric personal relations. The current study revealed that there are statistically significant relationships between most items under staff member competences and behaviors and students' values. In this regard, Iacobucci et al. ${ }^{[32]}$ stated that professional values can vary among individuals due to differences in educational level, culture, learned experiences and work expertise. Moreover, Parandeh et al. ${ }^{[22]}$ asserted the importance of the acquisition and internalizing of professional values necessary in care settings for professional development and as a framework for decision making and ethical practice, contributing to individuals' professional commitment.

Finally, in Egypt, Abd Elkader et al. ${ }^{[33]}$ highlighted that unethical behaviors in nursing education are emergent problems that seriously disrupt the teaching-learning environment and often result in stressful student-faculty relationships. Nursing educators who demonstrate positive, respectful behaviors encourage similar behaviors from their students. Conversely, educators who are aloof, disinterested and demeaning may invoke their students' hostility. From another approach of 
views, Demirkasimoglu ${ }^{[34]}$ mentioned that it is possible to say that teacher professionalism is defined as a focus on teachers' professional qualifications, such as "being good at his/her job", "fulfilling the highest standards", and "achieving excellence". Nurse educators need to apply professional competencies that translate into ethical behaviors in order to encourage a positive student-instructor relationships and to create a safe and nurturing environment.

\section{CONCLUSION AND RECOMMENDATIONS}

Nursing students must have values that shaping their behavior and attitude as future professional nurses, to implant and sustain these values, existence of role model is a must, through translating the values through (unseen education) or behind their teaching session. Based on the study results, it can be concluded that the values of mercy, honesty and patience are major components of the professional competencies and positive behavior of faculty staff members. It is recommended to enhance the scientific and professional level of faculty staff by continuous training and scholarships for such education. Faculty staff must pay attention to guide students to maintain positive behavior and stress the importance of personal and professional students' values, which are reflected in their clinical nursing practice.

\section{CONFLICTS OF INTEREST Disclosure}

The authors declare that there is no conflict of interest.

\section{REFERENCES}

[1] Tope O. Effects of teachers' personality on secondary school discipline: case study of some selected schools in Nigeria, 1sted, Ego Booster Books Co, Ogun State, Nigeria; 2010. 22 p.

[2] Nabukenya M. Influence of teachers' professionalism on teacher performance in busirocouty secondary schools, Wakiso district, published Master thesis in educational management and administration, Makerereuniversity; 2010. 11 p.

[3] Evans L. Professionalism, professionally and the development of education professionals. British Journal of Educational Studies. 2008; 56 (1): 20-38. http://dx.doi.org/10.1111/j.1467-8527. 20 $07.00392 . x$

[4] Boyt TE, Lusch RF, Naylor G. The role of professionalism in determining job satisfaction in professional services: a study of marketing researchers. Journal of Service Research. 2001; 3 (4): 321-330. http://dx.doi.org/10.1177/109467050134005

[5] European commission education and training, supporting teacher competency development for better learning outcomes; July 2013. 15 p. Available from: http://ec. europa.eu/education/schoo 1-education/teacher-cluster_en.htm

[6] AL-Shdifat B. The professional competencies are possessed by educational supervisors of social studies from viewpoint of social studies teachers in Qasbat Al-Mafraq-Jordan. Research on Humanities and Social Sciences. 2014; 4(28): 122-134.

[7] Hammer DP. Professional Attitudes and Behaviors: The "A's and B's" of Professionalism. American Journal of Pharmaceutical Education. 2000; 1(64): 1-9.

[8] Gokenbach V. Professionalism in Nursing: What Does It Really Mean? Dec 27, 2013. Advance your nursing career online. Available from: http://www.nursetogether.com/professionalism-i n-nursing-what-does-itre\#sthash.JtE408Ti.dpuf

[9] Açıkgöz F. A study on teacher characteristics and their effects on students attitudes. The Reading Matrix. 2005; 5(2): 3-8.

[10] Gourneau B. Five Attitudes of Effective Teachers: Implications for Teacher Training, University of North Dakota; 2000.

[11] Shaw HK, Degazon C. Integrating the core professional values of nursing: a profession, not just a career. Journal of Cultural Diversity. 2008; 15(1): 44-50. PMid:19172979.

[12] Cherie A, Mekonen AH, Shimelse T. Introduction to Professional Nursing and Ethics, Addis Ababa University In collaboration with the Ethiopia Public Health Training Initiative, The Carter Center, the Ethiopia Ministry of Health, and the Ethiopia Ministry of Education; 2005. 1 p.

[13] Lavin MA, Davis TL, Carr DL. The Impact Of Instructor Attire On Student Perceptions Of Faculty Credibility And Their Own Resultant Behavior. American Journal of Business Education. 2010; 3(6): 51-56.

[14] Lovat T, Toomey R. Values Education and Quality Teaching. Springer Science+Business Media; 2009. 5 p.

[15] Farenwald NL, Bassett SD, Tschetter L, et al. Teaching core nursing values. Journal of Professional Nursing. 2005; 21(1): 465. PMid:15682160. http://dx.doi.org/10.1016/j.profnurs . 2004.11 .001

[16] Lovat T, Hawkes N. Values Education: A Pedagogical Imperative for Student Wellbeing. The University of Newcastle, Australia; 2012. 25 p.

[17] Alkandari N. The level of student incivility: The need of a policy to regulate college student civility. College Student Journal. 2011; 45(2): $257-268$

[18] Shah SS. Impact of teacher's behavior on the academic achievement of university students, published doctorate thesis in education, Arid Agriculture University, Institute of Education and Research, Rawalpindi, Pakistan; 2009. 31 p.

[19] Eisa HZ, Elnaqaa SA. Identification of the competencies possessed by the professional members of the faculty of Education in the Islamic university as student perceived in the light of total quality management, 2nd education conference (higher education role in total improvement), Islamic university, Gaza; 2008. p. 14-18.

[20] Hoffman RL. Differences in student perceptions of student and faculty incivility among nursing program types: An application of attribution theory, Published doctorate thesis in Philosophy, Indiana University of Pennsylvania; 2012. p. 246-248.

[21] AlOsaimi MA. The practical manners in the holy qura'an how the students of the teachers collage committed to them, from the point view of the students and theteaching staff, published master thesis, faculty of education, omElqoraa university, kingdom of Saudi Arabia; 2006. $45 \mathrm{p}$.

[22] Parandeh A, Khaghanizade M, Mohammadi E, et al. Factors Influencing Development of Professional Values Among Nursing Students 
and Instructors: A Systematic Review. Global Journal of Health Science. 2015; 7(2): 13-17.

[23] Kavas M, Demirören M, Koşan AM, et al. Turkish students' perceptions of professionalism at the beginning and at the end of medical education: a cross-sectional qualitative study. Medical Education Online. 2015; 23(2): 12-19.

[24] Wesson RH. The impact of performance skills on students' attitudes towards the learning experience in higher education Issues in Educational Research. 2011; 21(1): 22-26.

[25] Copriady J. Teachers competency in the teaching and learning of chemistry practical. Mediterranean Journal of Social Sciences. 2014; 5(8): 312-318.

[26] Wilfong D, Szolis C, Haus C. Nursing school success: Tools for constructing your future. Sudbury, MA: Jones and Bartlett; 2007. 4 p.

[27] Camp MD. The power of teacher -student relationships in determining student success, published doctorate thesis in education, Faculty of the University, Missouri-Kansas City; 2011. 12 p.

[28] Reimers F. Citizenship, identity and education, examining the public purposes of schools in an age of globalization. Citizenship education globalization and democratization. 2006; 4(9): 4-9.
[29] Alt D, Reingold R. Moral Development and Citizenship Education: Changes in teachers' moral role, 1st ed, Sense Publisher Co, Boston; 2012. $6 \mathrm{p}$.

[30] Altiok HO, Üstün B. Meaning of Professionalism in Nursing Students. American International Journal of Social Science. 2014; 3(6): 33.

[31] Mercader V. Study of the ethical values of college students,Published Department of doctorate thesis in Educational Leadership and Policy Studies, College of Education, University of South Florida; 2006. 44 p.

[32] Iacobucci TA, Daly BJ, Lindell D, et al. Professional values, selfesteem, and ethical confidence of baccalaureate nursing students. Nursing Ethics Journal. 2013; 20(4): 479-490. PMid:23166146. http://dx.doi.org/10.1177/0969733012458608

[33] AbdElkader AM, Aref SM, Abood SA. Perception of Unethical Behaviors among Nursing Educators, Students, and Staff in El Minia University. J Am Sci. 2012; 8(12): 75.

[34] Demirkasimoglu N. Defining "Teacher Professionalism" from different perspectives. Procedia Social and Behavioral Sciences. 2010; 9: 2049-2051. 